\title{
STATE TAXATION OF NATIONAL BANKS
}

The subject is a large-sounding one, but because of a single fact its scope is narrow. That fact is that without the permission of Congress there could be no such taxation. The fact is, therefore, an act giving the permission conditionally, so that the treatment of the subject resolves itself into an examination only of the condition and an ascertainment, as far as may be, of its scope and dimensions.

As far as may be. This qualification of the desired ascertainment is made advisedly so as not to arouse the hope of the student of the question that even in a majority of instances he will be able to write after his solution the quod erat demonstrandum of academic days, which comfortable conclusion he may reasonably append to his opinions upon many problems of law propounded by his clients. The reason is not far to seek, for immediately upon the submission of the question as to whether or not a given State tax upon national bank shares is a discrimination, we enter upon a fog-region of judicial definition, distinction, counterdefinition and dissent in comparison with which any twilight-zone of constitutional law loses any distinctive terrors of uncertainty which it may have been thought to possess. That this statement is not exaggerated appears from the fact that from a recent decision of the Supreme Court holding invalid a State tax upon national banks, four of the nine members of the Court dissented, the minority opinion commencing with the somewhat unusual assertion that "a grievous wrong" was done by the decision to the State which had sought to impose the tax. In a word, it behooves the judge or lawyer whose opinion is invoked upon a case in point to sound the fog-horn and proceed at the most on half speed.

Coming now from the general to the concrete, we find that the only factors of any degree of substance whatever are two in number and that after leaving the last we are upon the open sea. These are, first, the proposition above mentioned, that without the consent of the Federal government, a State may not impose any tax upon a national bank. ${ }^{I}$

"Upon what principle is the power of a State to tax the power of a national bank, without the consent of Congress, denied? The

${ }^{1}$ Talbott v. Silver Bow County, I39 U. S. 438. 
answer to this question was fully given by Chief Justice Marshall in the case of $M c$ Culloch v. Maryland, 4 Wh. $3 \mathrm{I} 6$; Weston v. Charleston, 2 Pet. 449. Briefly stated, the argument was this: Two distinct sovereignties, the State and the United States, exercise jurisdiction within the same territorial limits. Each has the power of taxation. This power is in its nature absolute and unlimited. Power to tax is power to destroy. Given to the State the power to tax any of the instrumentalities which the United States creates for the exercise of its jurisdiction, and the former may impede, if not wholly stop, the latter in the discharge of its duties as sovereign. Hence, by necessary implication, the absolute exemption from state taxation of any of the instrumentalities-and among them are national banks-which the United States creates for the exercise of its powers and the discharge of its duties."

The second factor is that the requisite consent of Congress is given by R. S. U. S., $\$ 5219$, which is as follows:

"Nothing herein (national banking act) shall prevent all the shares in any association from being included in the valuation of the personal property of the owner or holder of such shares, in assessing taxes imposed by authority of the State within which the association is located; but the legislature of each State may determine and direct the manner and place of taxing all the shares of national banking associations located within the State, subject only to the two restrictions, THAT THE TAXATION SHALL NOT BE AT A GREATER RATE THAN IS ASSESSED UPON OTHER MONEYED CAPITAL IN THE HAND OF INDIVIDUAL CITIZENS OF SUCH STATE, and that the shares of any national banking association owned by non-residents of any State shall be taxed in the city or town where the bank is located, and not elsewhere. Nothing herein shall be construed to exempt the real property of associations from either State, county or municipal taxes, to the same extent, according to its value, as other real property is taxed."'

\footnotetext{
$=$ The national banking act of I864, in addition to the restrictions now imposed upon State taxation of national bank shares, declared that "the tax so imposed under the laws of any State, upon the shares of any of the associations authorized by this act, shall not exceed the rate imposed upon the shares in any of the banks organized under the authority of the State where such association is located." In the reennactment of this statute in I868 (R. S. U. S., \$5219), the standard was changed from State bank shares to "other moneyed capital," etc.
} 
For the purposes of this inquiry, only the first of these "two restrictions" will be considered, Congress having worded its meaning as to the second and as to the real estate of a national bank with a clearness which cannot be said to pervade the section. Had its draughtsman been given, even for a moment, a seer's vision-could he have foreseen the conflicting constructions, the apparently endless succession of State laws to be submitted to his standard, the reams of printed matter devoted exclusively to the discussion of what he probably meant, and, most serious of all, could he have foreseen the uncertainty of State legislatures and taxing officers extending sometimes to the imperilling and sometimes to the derangement of an entire scheme of State taxation, due only to the looseness of his phraseology-it goes without saying that he would surely have recast the section and would have prescribed a limit of State taxation which would have been a limit indeed and not a predicate for a guessing contest.

But the section was so written and Congress has not attempted to elucidate its meaning by amendment since its passage in I868. What, then, is the meaning of the words, "other moneyed capital in the hands of individual citizens"?

On these few words hang the law of the question and incidentally a half century of discussion. It is not practicable to present within the limitations of a single article in a Law Journal all of the decisions in point. We must content ourselves with certain of the leading cases and endeavor to gather from them the law of the subject as it is to-day.

In First National Bank v. Kentucky, 9 Wall. 353, the basal law governing the relations of a State to a federal agency was set forth with characteristic clearness by Mr. Justice Miller, who, after mentioning the repeated re-affirmations by the court of McCulloch v. Maryland, supra, said:

"But the doctrine has its foundation in the proposition that the right of taxation may be so used in such cases as to destroy the instrumentalities by which the government proposes to effect its lawful purpose in the States, and it certainly cannot be maintained that banks or other corporations or instrumentalities of the government are to be wholly withdrawn from the operation of State legislation. $* * * *$ They (the national banks) are subject to the laws of the State, and are governed in their daily course of business far more by the laws of the State than of the Nation. All their contracts are governed and construed by State laws. Their acquisition and transfer of property, 
their right to collect their debts, and their liability to be sued for debts, are all based on state law. It is only when the State law incapacitates the banks from discharging their duties to the government that it becomes unconstitutional. We do not see the remotest probability of this, in their being required to pay the tax which their stockholders owe to the State for the shares of their capital stock, when the law of the Federal Government authorized the tax."

Accordingly a tax by the State of Kentucky upon the shares of stock of a national bank was pronounced valid, the court declining to consider the question of "other moneyed capital" upon the ground that it had not been sufficiently raised in the lower court. The court held further that while a State cannot tax the capital of a national bank, a tax upon shares is not a tax upon capital.

The following propositions touching "other moneyed capital" appear to be established by decisions of the same court:

First, the purpose of the statute was to protect national banks from unfriendly discrimination by the States in the exercise of their taxing power-that is, discrimination quoad other moneyed capital. $^{3}$ This, however, applies only to moneyed capital in the hands of individuals and excludes it in the hands of corporations. ${ }^{4}$

Second, Section 5219 does not forbid discrimination between national banks, but only as between such banks and State banks or other moneyed capital in the hands of private individuals.

Third, If State and national banks are treated equally from the standpoint of assessment, there is no illegal discrimination. ${ }^{6}$

There seems to have been no attempt at judicial definition of the phrase until I886, when the Supreme Court in Mercantile National Bank v. New York, supra,-the leading case in point to-dayafter instancing several cases of noncompeting moneyed capital, said:

"The terms of the Act of Congress, therefore, include shares of stock or other interests owned by individuals in all enterprises in which the capital employed in carrying on its business is money, when the object of the business is the making of profit by its use as money. The moneyed capital thus employed is invested for that purpose in securities by way of loan, discount or otherwise, which are

${ }^{3}$ Adams v. Nashrille, 95 U. S. I9.

"Mercantile National Bank v. New York, I2x U. S. I38.

${ }^{*}$ Merchants National Bank v. Pennsylvania, I67 U. S. $46 \mathrm{I}$.

- First National Bank v. Chapman, 173 U. S. 205. 
from time to time, according to the rules of the business, reduced again to money and re-invested. It includes money in the hands of individuals employed in a similar way, invested in loans or in securities for the payment of money, either as an investment of a permanent character, or temporarily with a view to sale or re-payment and re-investment. In this way the moneyed capital of individuals is distinguished from what is known generally as personal property."

This read well, but as a definition seems to have proved inadequate, for its enunciation was contemporaneous with a beginning of a succession of cases asking a definition by the same court of the word "similar"- "money in the hands of individuals employed in a similar way." That inquiry has continued to the present time, and the prediction may safely be made that it will and in the nature of things must continue as long as our forty-eight States enact statutes not heretofore substantially passed upon or until Congress amends section 5219 in such a manner as to place its meaning beyond doubt.

"Similar." Is the business of a trust company similar tonote, not the same as-that of a bank? The court in the Mercantile Bank case holds that it is not. It was claimed for the bank that the New York statute expressly exempted from taxation in the hands of individual citizens numerous kinds of moneyed capital, aggregating more than one and a half billion dollars, while national and State bank shares were subjected to taxation upon their full actual value, less the real estate owned by the bank. The exemptions were as follows:

I. Shares of stock in the hands of individuals deriving income or profit from their capital, or otherwise, not including trust companies and State and National Banks.

2. Trust companies and life insurance companies.

3. Savings banks and the deposits therein.

4. Certain municipal bonds of the City of New York.

5. Shares of stock in corporations created by States other than New York in the hands of individual shareholders, residents of New York.

It was argued that these exemptions brought the case within the first of the two restrictions of section 5219 and within the ruling in Boyer v. Boyer, II3 U. S. 689, as making the tax upon shares of national bank shares an unfair discrimination against that class of property. In the Boyer case the court had held that 
its former decisions do not sustain the proposition that national bank shares may be subjected under the authority of a State to local taxation where a very material part, relatively, of other moneyed capital in the hands of individual citizens within the same jurisdiction is exempted from such taxation, the court saying, "Capital invested in national bank shares was intended to be placed upon the same footing of substantial equality in respect of taxation by State authority, as the State establishes for other moneyed capital in the hands of individual citizens, however invested, whether in state bank shares or otherwise."

The court, however, held that the record in the Mercantile Bank case showed no unfair discrimination. For its reasons, reference must be made to the opinion, the substance of which is contained in the following paragraph:

"'Moneyed capital' does not mean all capital the value of which is measured in terms of money. In this sense all kinds of real and personal property would be embraced by it, for they all have an estimated value as the subjects of sale. Neither does it necessarily include all forms of investment in which the interest of the owner is expressed in money. Shares of stock in railroad companies, mining companies, manufacturing companies, and other corporations, are represented by certificates showing that the owner is entitled to an interest, expressed in money value, in the entire capital and property of the corporation, but the property of the corporation which constitutes its invested capital may consist mainly of real and personal property, which, in the hands of individuals, no one would think of calling moneyed capital, and its business may not consist of any kind of dealing in money or commercial representatives of money."

The court said that trust companies are not banks in the commercial sense of that word, although they receive money on deposit and invest it in loans and so deal, therefore, in money and securities.

This ruling was followed in Jenkins v. Neff, I86 U. S. 230, another trust company case, in which the court went so far as to hold that no power to loan, discount or purchase commercial paper was given trust companies by a New York statute authorizing them to exercise the powers conferred on individual banks and bankers by another statute providing that such banks and bankers may "take, receive, reserve and charge on every loan or discount made, or upon any note, bill of exchange, or other 
evidence of debt, interest at the rate of $6 \%$ per annum; and such interest may be taken in advance."

Without stopping to enlarge upon what seems to the writer the patent inaccuracy of this proposition, it would appear to follow necessarily therefrom that the trust companies of $\mathrm{New}$ York have, unless subsequent State legislation has expressly conferred it, no power to loan money in any of the methods prescribed. Yet we know as a fact that their transactions of this nature average millions of dollars monthly.

Another interesting feature of the rtiling is that the court qualified materially the rule of "competitive moneyed capital," which it had formulated in cases like First National Bank v. Chapman, supra, and substituted in lieu thereof "limited competition," which was declared permissible. "It is essential," said the court, "if the law of the State is to be declared invalid under the limitations expressed in the United States statute, that the enactment of the legislature shall evidence a disposition to evade or override the spirit of the limiting statute; and this is clearly not the case where it provides for equal taxation upon its own state banks, and where it does not require its trust companies, which, it may be conceded, come into limited competition with the investors in the shares of national banks, to invest their capital in such a way as to necessarily exempt them from taxation upon a portion of their capital stock."

So, then, a discrimination in favor of competing moneyed capital is not obnoxious to section 5219 , provided the competition is limited. The court would have contributed materially to a clearer understanding of the subject if it had drawn the line of limit.

But further, it is provided by section $2 \mathrm{I}$ of the Federal Reserve Act that the Reserve Board may, among other things,

"grant by special permit to national banks applying therefor, when not in contravention of State or local law, the right to act as trustee, executor, administrator, or registrar of stocks and bonds, under such rules and regulations as the said board may prescribe"-

in other words, may become a federal trust company.

Now, as to national banks availing themselves of this permission, what becomes of the competition or limited-competition test? Manifestly, it would seem, it cannot be invoked, for the competition is direct and unlimited. The great national banks of the 
country can more than hold their own with the largest trust companies chartered by State authority. The only conclusion appears to be that, as between such banks and trust companies, both doing business on "moneyed capital in the hands of individuals," the same rule and limit of State taxation must obtain and, if a lower rate is prescribed for the latter, or an exemption or deduction allowed them which is denied the banks, the legislation to those ends or any of them must be pronounced to be in conflict with the Act of Congress and invalid.

Upon the general subject of discrimination, the leading case decided by the Supreme Court within the last decade is that of San Francisco National Bank v. Dodge, I97 U. S. 70, in which it was held that such discrimination results from the taxation of national bank shares under the Political Code of California at their market value, while the construction given by the highest State court to the provisions for the taxation of the "property" of State banks and other moneyed corporations does not require, although property is defined by the Constitution of California as including "franchises," that the assessing officers shall include in the assessment all the intangible elements of value which form part of the market and selling value of the stock.

Four members of the court dissented from the judgment, concurring in the minority opinion of Mr. Justice Brewer, the first sentence of which, as hereinbefore noted, contains an expression of his belief that by the judgment "a grievous wrong is done to the State of California."

A few words as to deductions. The earlier decisions bravely maintained the proposition that the taxation of national bank shares by a State statute, without permitting the shareholder to deduct from their assessed value the amount of his bona fide indebtedness, as in the case of other moneyed capital, is a discrimination forbidden by the Act of Congress. Evansville National Bank v. Britton, I05 U. S. 322 ; Supervisors v. Stanley, Id. 305; Hills v. Exchange National Bank, Id. 319. In the first named case the court said:

"The Act of Congress does not make the tax on personal property the measure of the tax on bank shares in the State, but the tax on moneyed capital in the hands of the individual citizens. Credits, money loaned at interest and demands against persons or corporations are more purely representative of moneyed capital than personal property, so far as they can be said to differ. **** The rights, credits, demands and money at interest mentioned in the 
Indiana statute, from which bona fide debts may be - deducted, all mean moneyed capital invested in that way."

Later cases, however, like First National Bank v. Chapman, supra, and Commercial National Bank v. Chambers, I8z U. S. 556 , have materially lessened the force of the early deliverances, the court in the Chapman case holding that the fact that the owner of what is termed "credits" in the State statute is permitted to deduct certain classes of debts from the sum of those credits, upon the remainder of which taxes are to be assessed, while the national bank stockholder is not permitted to deduct his debts from the value of his shares, does not in itself constitute an illegal discrimination. Again the line grows dim.

And dimmer still. In People v. Weaver, roo U. S. 539, it was held that a statute of New York which permitted a debtor to deduct the amount of his debts from the valuation of all his personal property, including moneyed capital, except his bank shares, taxes those shares at a greater rate than other moneyed capital and is, therefore, void as to the shares of national banks. But in Amoskeag Savings Bank v. Purdy, 23I U. S. 373, decided December I, I9I3, the court, after twelve months' consideration, held that provisions in the New York tax law imposing a flat rate on shares of all banks, both State and national, without the right of exemption (deduction?) in case of the indebtedness of the owners, does not discriminate against national banks and is not invalid under section 5219. The interested reader must himself locate the distinction which the court says exists between this and the Weaver case, videlicet, in the State statutes pertinent to the two cases.

New York and Kentucky have been among the States the most persistent and the most successful in the effort to whittle down section $52 \times 9$ and to make it a bar to State taxation in name only. As has been seen, New York bore her part in the early battles but must share her recent honors with Kentucky. In Covington v. First National Bank, I98 U. S. I00, a statute of the latter State, passed in I900, taxing shares of national banks from the years I893 to I900, was held void as to those portions which were retroactive and valid as to taxes imposed thereafter. Not disconcerted, that State made up another case, Citizens National Bank v. Kentucky, 217 U. S. 443, in which it was held that the retroactive features of the same statute do not, so far as the shares of resident shareholders are con- 
cerned, operate to discriminate against the bank nor to deny due process of law, further, that as no non-resident stockholders were parties complainant, the judgment of the State court sustaining the tax would be affirmed. Mr. Justice White was constrained to dissent because he thought, in substance and effect, "the retroactive tax now upheld is a tax on the bank and its assets and is therefore void."

The latest reported decision is that of Lacy v. Mc.Cafferty, 2I5 Fed. 352, in which the Circuit Court of Appeals for the Eighth Circuit held in June of this year that the assessment of property of national banks at its full value, while other classes of property are assessed at only sixty per cent of their fair cash value, does not entitle a national bank to relief in equity. Note the reason"it must further appear," says the court, "that the assessing officers made the erroneous valuation not accidentally or inadvertently, but systematically and intentionally with respect to one or more classes of property, with the intention of imposing upon that class an undue burden of taxation."

It seems to the writer that this is a case of res ipsa loquitur for the opposite conclusion. Just why, upon a conceded difference of forty per cent. in the assessments, the national banks should have to prove a prescribed mental condition on the part of the assessors-that this difference was not inadvertent but intentional-before relief can be granted even in "equity," passes his comprehension. When section 5219 was enacted, it must have been thought to possess teeth, but if so, they have practically disappeared under the skillful dental surgery of the tax-hungry States. The grinders have ceased because they are few.

What is an "intentional and systematic" discrimination, if a difference of forty per cent. in assessment is not so? In First National Bank v. Albright, 208 U. S. 548, it was said, "accidental inequality is one thing, intentional and systematic discrimination another." The court declined to enjoin an assessment because the proper time had not arrived. "Probably," it added significantly, "it will be made with caution after this case."

After this series, necessarily incomplete, of distinctions and sub-distinctions, how clear and virile are the words of Mr. Justice Bradley in Supervisors v. Stanley, supra, in an opinion dissenting from that of the majority only upon the ground that it did not reach the heart of the difficulty-did not declare the true intent of Congress-did not then (I882) forever establish the principles of the law and place them not merely beyond reasonable doubt, 
but beyond the ingenuity of State-taxing officers looking longingly upon a fair but forbidden field!

The opinion is as follows, the italics being those of the writer of the opinion:

"I dissent from the judgment of the court in all these cases, for the reason that, in my opinion, the State laws authorizing the capital stock of national banks to be taxed, without allowing any deductions for the debts of the stockholders, where such deduction is allowed in relation to other moneyed capital, are void in toto so far as relates to national banks. To hold the laws valid except as to those who are actually indebted, and actually claim the benefit of the deductions, and actually set it up in a suit brought by the bank for relief, is practically to render the condition of the act of Congress nugatory, and to deprive the national banks and their stockholders of its protection. The tax though laid on the stockholders is required to be paid by the bank itself, which must pay without deduction unless the shareholders give the bank notice of the amount of their debts. This is a most ingenious expedient to avoid such deductions altogether. The probability that not one in ten of the shareholders will ever have notice of the assessment in time to make the claim, and the natural reluctance they would have (if they had notice) to lay the amount of their debts before a board of bank officers, will effectually secure the State from claims for deduction. And that was, no doubt, the object of the law. But this unequal operation of it, in its practical effect, might not be sufficient to render it void. It is void, in my judgment, because it makes no exception, but is general in its terms, subjecting to taxation the stock of national banks without the privilege of deducting debts. Denying to it operation and effect as to those who desire to claim the benefit of the deduction, and giving it effect as to all others, is to tear a portion of the law out by the roots. It is not like a case where a portion of a law, which may be separated from the rest, can be declared invalid, without affecting the remainder of the law; nor like the case of a general law which the Legislature has power to make, but from the operation of which some individuals may have a legal or constitutional exemption, which they can plead in their defense; but it is wrong in form, worong in toto. The Legislature had no authority to make the capital of national banks taxable except in the same manner as other moneyed capital of the State. The practical iniquity of the law is seen in this, that it affects the value of all the stock whoever holds it. As the law stands it acts as a prohibition against the purchase of stock by those who owe debts, and they constitute a considerable portion of 
every community. It does not help the validity of the law for us to declare that it is pro tanto void, and, in fact, make a new law for the State. Its validity must be decided by its actual form and terms. If these cannot stand, the law is void."

It must now be evident that there has been a great drift in the law of the subject since the enactment of the Statute in I868. It must be equally evident to those who think that national bank shares are entitled to a greater measure of protection from intentionally unfriendly and discriminatory State taxation than they now receive that they cannot hope to obtain this otherwise than through Congressional action. What form should this take? Replies without number might be made to the question, all of - them doubtless worthy of consideration. The most effective solution of the problem, however, in the judgment of the writer, is suggested by Mr. Justice Harlan in his opinion in Boyer v. Boyer, supra:

"As the Act of Congress does not fix a definite limit as to the percentage of value beyond which the States may not tax national bank shares, cases will arise in which it will be difficult to determine whether the exemption of a particular part of moneyed capital in individual hands is so serious or material as to infringe the rule of substantial equality."

If Congress will amend section 52 I9 and fix, say, sixty per cent. as a definite limit beyond which the States may not tax national bank shares, the end will be attained, the clouds through which we have been groping our way will disappear and only the memory of them as interesting illustrations of legal casuistry will remain. If, to be more specific, the first of the "two restrictions" of section 52 I9 be amended and reënacted so as to read

"that the assessment of such shares shall not be at a greater rate than sixty per cent. of their book value,"

there will be an end of construction, for there will be nothing to construe. All that will remain will be obedience to the supreme law of the land.

Of course, when the amending bill is introduced, there will be protests both loud and deep-forty-eight of them, perhaps. But these ought not by their mere number and volume to drown the voice of justice-the justice which has been so long lost sight of ; 
the justice which is predicated upon the elementary requirements of the jurisprudence of taxation, uniformity and equality; the justice which denies altogether the reason and righteousness of a system of taxation which lays its hand upon those forms of property which are visible and within reach, and arbitrarily assesses other subjects of taxation, receiving the same governmental protection, at fifty, forty or thirty per cent. of their value, or, with blinking eye, permits them to escape altogether.

George Bryan.

RICHMOND, VIRGINIA. 